\title{
How Social Dominance Orientation Affects Union Participation: The Role of Union Identification and Perceived Union Instrumentality
}

\author{
EVA G. T. GREEN and FANJA AUER \\ University of Lausanne, Lausanne, Switzerland
}

\begin{abstract}
Bridging social dominance theory and labour studies, this field study investigated the mechanisms underpinning the relationship between rejection of group-based domination and participation in union activities. Respondents $(N=135)$ were members of a public sector union in California, that is, a hierarchy-attenuating institution. Results revealed that union identification mediated the negative relationship between social dominance orientation and active union participation. Moreover, the mediational effect of union identification was moderated by perceived union instrumentality (i.e. outcome- and process-based benefits afforded by the union), indicating that the relationship between union identification and participation was stronger among those union members who consider that the union affects workplace justice. The findings reveal the importance of both identity-based and instrumental motivations underlying union participation. The novelty of applying social dominance theory to union behaviour is underscored. Copyright (c) 2012 John Wiley \& Sons, Ltd.
\end{abstract}

Key words: social dominance theory; hierarchy attenuation; union participation; union identification; perceived instrumentality

In the United States, the labour movement has suffered an important decline in the last 25 years: unions lost approximately 5.2 million members in both private and public sectors with membership rates sinking to $12.5 \%$ in 2004 (Chaison, 2006). Despite declining participation, the public still thinks labour unions are necessary to protect the working person (Panagopoulos \& Francia, 2008). As active members mainly contribute to achieving the goals of unions, it is crucial for the survival and vitality of unions to understand the motivations driving union members to participate in formal (e.g. participation in union meetings and rallies) and informal (e.g. helping another member to know about the union) union activities. Understanding motivations to participate in union activities can also uncover

\footnotetext{
*Correspondence to: Eva G. T. Green, Institute for Social Sciences, Faculty of Social and Political Sciences, Vidy, University of Lausanne, CH-1015 Lausanne, Switzerland.

E-mail: eva.green@unil.ch
} 
reasons why individuals decide to join, leave or never join a union and thus further indicate effective recruitment policies and organising strategies for unions to reduce union decline (Prowse \& Prowse, 2006). Previous research has shown that work-related factors (e.g. job satisfaction, organizational commitment), socio-demographic characteristics (e.g. age, sex, ethnicity, occupational level), members' perceptions and attitudes towards unions, group identification and ideological beliefs such as the work ethic and Marxist beliefs predict union participation (e.g. Aryee \& Chay, 2001; Fullagar \& Barling, 1989; Johnson \& Jarley, 2004; Kelly \& Breinlinger, 1996; Newton \& Shore, 1992; Sverke \& Kuruvilla, 1995; see Bamberger, Kluger, \& Suchard, 1999 for a meta-analysis).

As unions promote and fight for fair working conditions and wages, it is important to examine the degree to which union members' world views concerning non-egalitarian and hierarchically structured social systems affect their participation in union activities. Bridging social dominance theory and labour studies, we thus introduce a new predictor of union participation: individuals' desire for or rejection of group-based dominance. The current study brings a novel focus to social dominance theory as, to our knowledge, union participation has not previously been investigated from this angle (Sidanius \& Pratto, 1999). After discussing social dominance theory in the context of labour unions, we concentrate on the role of two different type of antecedents of pro-union behaviour-union identification and perceived union instrumentality-in underpinning the relationship between social dominance orientation (SDO) and active union participation. We then present a survey study on pro-union behaviour carried out among members of a Californian labour union.

\section{SOCIAL DOMINANCE AND UNION PARTICIPATION}

The central objective of social dominance theory is to understand how and why human social systems tend to be organized and perpetuated as group-based hierarchies (Pratto, Sidanius, \& Levin, 2006; Sidanius \& Pratto, 1999). In stratified social systems, dominant groups enjoy a disproportionate share of resources, power and positive social value compared with subordinate groups. Institutions within society contribute to the stability of existing group-based hierarchies. Whereas these hierarchies are to a great extent created and maintained by hierarchy-enhancing (HE) social institutions (e.g. police forces), hierarchy-attenuating (HA) institutions (e.g. civil rights groups, welfare organizations) defend subordinate social groups with the aim to facilitate an egalitarian distribution of resources (Haley \& Sidanius, 2005; Pratto et al., 2006; Sidanius \& Pratto, 1999). Unions protect and empower workers by engaging in collective bargaining with their employers to reduce power differences between employees and employers and to reduce socio-economic inequalities among employees in general (Cornfield, 1991). From a social dominance theory perspective then, labour unions are considered HA institutions. Union activism embodies counterdominance serving to attenuate hierarchical social arrangements (see Henry, Sidanius, Levin, \& Pratto, 2005).

Social dominance theory argues that the values represented by institutions tend to be congruent with values of individuals within them such that HE institutions will tend to be occupied by individuals supporting group-based hierarchies, whereas HA institutions will tend to be occupied by those who hold egalitarian values and reject group-based hierarchies (Haley \& Sidanius, 2005 for self-selection and socialization explanations of this phenomenon, see also Guimond, Dambrun, Michinov, \& Duarte, 2003). Individual differences in support for group-based social hierarchy are indexed by SDO that captures 
a desire for group dominance and social inequality (Pratto, Sidanius, Stallworth, \& Malle, 1994). Importantly, SDO taps an abstract, generalized acceptance or rejection of a hierarchical society that translates into more concrete attitudes, such as positioning towards unions, or behaviour. People with high levels of SDO have been shown to oppose policies that increase equality between groups (e.g. welfare, affirmative action), whereas those low on SDO have been shown to hold more favourable attitudes towards such policies. Thus, from a social dominance perspective, HA principles of unions are compatible with the egalitarian values of individuals low in SDO who consequently should exhibit pro-union behaviour and be more active in participating in union activities. Such counterdominant behaviour of low SDO individuals is subversive to the hierarchical order between employers and employees.

Hypothesis 1: SDO will be negatively related with union participation such that union members who are low in SDO participate more in union activities than members who are high in SDO.

In the current study, we examine self-reported behaviour, the participation in both formal union activities that occur only occasionally (e.g. attending a union meeting; serving as a union steward) and informal activities (e.g. encouraging other members to support the union) that occur on a day-to-day basis in an unstructured way (e.g. Fullager, Clark, Gallagher, \& Carroll, 2004).

\section{HOW UNION IDENTIFICATION AND PERCEIVED UNION INSTRUMENTALITY AFFECT THE RELATIONSHIP BETWEEN SDO AND UNION PARTICIPATION}

Although SDO is expected to relate to union participation, the mechanisms underlying this relationship require further exploration: Why and how does opposition to group-based dominance lead to pro-union behaviour? Social dominance theory has demonstrated that, on the one hand, attitudes, values and beliefs that promote group-based inequality provide justifications for institutional practices distributing unequal social value in society (Sidanius, Levin, \& Pratto, 1996; Sidanius \& Pratto, 1999). Egalitarian values, on the other hand, justify practices enhancing equality. Values and beliefs (or legitimizing myths in the social dominance theory terminology) serve as links through which SDO relates to endorsement of HE or HA policies. Thus, mediational processes between SDO and union participation behaviour need to be considered. A dual-pathway model of collective action (see Stürmer \& Simon, 2004; see also Blader, 2007) helps define the type of values and beliefs that are relevant mediators in this process. This model bridges a social identity approach — underscoring collective identification processes (Haslam, 2001) — and a costbenefit analysis (Klandermans, 1997) and suggests that both underlie social movement participation. Collective identification represents intrinsic motivations on the basis of commitment to the movement, whereas a cost-benefit analysis reflects extrinsic, instrumental motivations for participation. These two factors could thus function as mediators accounting for the relationship between SDO and union participation. Similarly, labour studies literature argues that both identity-based and instrumental motivations underlie union participation (Aryee \& Chay, 2001; McFarlane Shore, Tetrick, Sinclair, \& Newton, 1994; Sverke \& Kuruvilla, 1995). Thus, these motivations should explain the justificatory process through which an abstract ideological belief (i.e. SDO) translates in to concrete behaviour: union participation. 
Identity-based motivations refer to identification with and affective attachment to the union as well as perceived value congruence between the member and the union, loyalty towards the union and union actions, a sense of pride of being a member and a desire to maintain membership. These motivations are important antecedents of the pro-union behaviour (Fullagar \& Barling, 1989; Fullagar et al., 2004; Kelloway \& Barling, 1993; Morrow \& McElroy, 2006; Sverke \& Kuruvilla, 1995; Tetrick, McClurg, Shore, \& Vandenberg, 2007; see also Bamberger et al., 1999). Union loyalty has been defined as positive feelings or affective attachment towards the union (Fullagar \& Barling, 1989, p. 213; Morrow \& McElroy, 2006, p. 77) and a desire to retain membership in the union (Fullager et al., 2004, p. 730). Thus, union identification and loyalty are considered equivalent in the current study. Blader (2007), for example, showed that identification with a union-organizing group predicted support for union certification as well as voting in favour of unionization. When union identity is salient, similarities between oneself and fellow union members are emphasized which transforms unique experiences of injustice into collective grievance (Stürmer \& Simon, 2004). Indeed, collective action can be seen as an 'expression of the individual's identification with and commitment to the union' (Kelly \& Kelly, 1992, p. 80). From a social dominance theory perspective, union identification also implies counterdominance motives rejecting the system in which employees are relegated to a subordinate position compared with employers (see Levin, Henry, Pratto, \& Sidanius, 2003). Union members should identify more strongly with their union insofar as they are low on SDO (an opposite pattern would be expected for employers, the high-status, dominant group in this intergroup setting). Union identification should in turn increase union participation. That is, to the extent that unions represent a struggle towards equality, a value incongruent with support for a hierarchically organized society, SDO should translate into a lack of identification with the union (identity-based justification) which would further decrease participation in union activities.

Hypothesis 2: The negative relationship between SDO and active union participation should be mediated by union identification motives, such that SDO will decrease union participation through a decrease of identification with the union. Union members who are low in SDO will identify more with the union and this will increase active union participation.

Instrumental motivations, in turn, are perceptions of unions' instrumental value to members and thus reflect a utilitarian relationship between the member and the union in the form of a cost-benefit analysis. Union instrumentality represents the members' perception of the union's ability to improve their workplace welfare regarding material benefits, unfair labour practices, job safety or general working conditions (Aryee \& Chay, 2001; Fullagar \& Barling, 1989; Morrow \& McElroy, 2006). In addition to union identification, perceptions of union instrumentality have been proven to increase participation to union activities (Fullagar \& Barling, 1989; Sverke \& Kuruvilla, 1995; Tetrick et al., 2007). To organize the scope of union instrumentality, Morrow and McElroy (2006) used an organizational justice framework distinguishing two components of perceived union instrumentality: outcomebased benefits and process-based benefits. Perceived outcome-based instrumentality represents individuals' assessments of the fairness of their benefits (e.g. work safety, pay) in relation to their inputs and their interaction with the union. Perceived process-based instrumentality assesses fairness of procedural benefits such as the effectiveness of the grievance procedure (e.g. Cohen-Charash \& Spector, 2001). Past research suggests that perceived union instrumentality (both outcome and process based) may play both a mediating 
and a moderating role in explaining union participation. Our study will shed light on the plausibility of these two alternative hypotheses.

In a study on union members in Singapore, Aryee and Chay (2001) demonstrated the mediating role of perceived union instrumentality in the relationship between workplace justice and different dimensions of union participation such as union turnover intentions and engaging in activities that help individual union members or the union as an organization. As union activities aim to attenuate unequal power relations in organizational hierarchies, those accepting societal hierarchy and inequality (higher SDO scores) should undermine the effect of union instrumentality (instrumental justification), decreasing their participation in union activities. Egalitarians (lower SDO scores) supporting HA process, in turn, should recognize union instrumentality as an effective means to reduce intergroup inequalities and thus increase their participation to union activities.

Hypothesis 3a: The negative relationship between SDO and active union participation should be mediated by perceived union instrumentality. SDO should decrease union participation through undermining unions' role in enhancing workplace justice.

However, prior research also suggests that the link between identity motivations and union participation is contingent upon union members' perceptions of the union as instrumental in bringing about change in the workplace and improving working conditions. For example, in a study on members of a multiracial South African union, Fullagar and Barling (1989) showed that perceived union instrumentality moderates the effect of union loyalty on union participation (for moderating affects of union instrumentality, see also Bamberger et al., 1999; Snape \& Redman, 2004; Youngblood, DeNisi, Molleston, \& Mobley, 1984). Moreover, Stürmer and Simon (2004) argued that highly identified group members also focus on the costs and benefits of group membership. Applying this reasoning to our research question, we therefore expect union identification to increase union participation as a function of perceived union instrumentality: The mediating effect of union identification in the relationship between SDO and pro-union behaviour should be intensified by union instrumentality, that is, the perceived effectiveness of the ways unions can contest and reduce intergroup inequalities at the workplace (e.g. Tan \& Aryee, 2002). In other words, if the mediation is framed in terms of a path model, as depicted in Figure 1, the moderating effect should apply to the second stage of the indirect effect between SDO and active union participation (Edwards \& Lambert, 2007). Perceived union instrumentality should moderate the path from union identification to union participation.

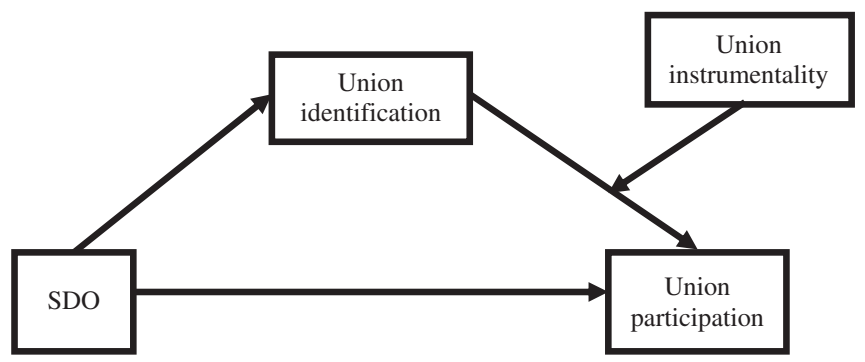

Figure 1. Moderated mediation: SDO, union identification and union instrumentality predicting union participation. 
Hypothesis 3b: The mediating effect of union identification on the relationship between SDO and active union participation should be moderated by perceived union instrumentality, such that perceived union instrumentality should intensify the effect of union identification on union participation.

\section{METHODS}

\section{Sample and procedure}

The data for this field study were obtained from members of a public-sector union in a big Californian city during an internship of the second author. Union field representatives distributed 400 questionnaires to members at their worksites and at union meetings. The questionnaires were filled out during breaks and returned to a response box at the union stands. Members participated on a voluntary basis and were informed that the survey was anonymous. Response rate was 35.5\%, with 142 returned questionnaires. After excluding incomplete questionnaires, the final sample consisted of 135 union members.

The sample composed of 16.5\% of European Americans, 33.1\% of African Americans, $33.8 \%$ of Latinos and $9.8 \%$ of Asian Americans (the remaining 6.8\% categorized themselves as other). Mean age was 46.1 years ( $S D=10.4$ years), and $56.7 \%$ were female. More than $85 \%$ of the respondents worked in the public sector, which is consistent with the actual percentage of public employed members of the union. The most common level of education was a bachelor degree $(38.5 \%)$ or a high school diploma $(29.6 \%)$. Average union tenure was 13.7 years $(S D=10.1$ years). These background variables were assessed in the end of the questionnaire.

\section{Measures}

Union participation - a self-reported behavioural measure-was our dependent variable and assessed with a nine-item scale (Johnson \& Jarley, 2004), where participants indicated 'how frequently during the last two years...' they had participated in informal and formal union activities such as discussed a work-related problem with a union representative or attended a union meeting or informational session. Responses varied from 1 (never) to 5 (always). An exploratory factor analysis yielded one factor grouping informal and formal union activities, thus a general union participation score was created $(\alpha=.91)$.

The links between union participation on the hand and SDO, union identification and union instrumentality perceptions on the other were examined (see Table 1 for means,

Table 1. Descriptive statistics and correlations between union participation, SDO, union identification, and perceived union instrumentality

\begin{tabular}{lccccc}
\hline & $M$ & $S D$ & 1. & 2. & 3. \\
\hline 1. Union participation & 3.30 & 1.09 & - & & \\
2. SDO & 2.12 & .66 & $-.19^{*}$ & - & $.40^{* *}$ \\
3. Union identification & 3.69 & .74 & $-.41^{* *}$ & - \\
4. Perceived union instrumentality & 3.64 & .74 & .02 & $-.28^{* * *}$ & $.51^{* *}$ \\
\hline
\end{tabular}

Responses on a 5-point scale ( 1 =never/strongly disagree, $5=$ always/strongly agree $)$.

$* p<.05 ; * * p<.01 ; * * * p<.001$; 
standard deviations and correlations). Response options for items tapping these measures ranged from 1 (strongly disagree) to 5 (strongly agree).

SDO was measured with eight items drawn from the 16-item Pratto et al. (1994) scale (four items tapping support for dominance and four reverse-coded items tapping approval of equality). A short version of the original scale was employed to keep the questionnaire brief. Examples of the SDO items were 'Some groups are just more worthy than others' (dominance) and 'Group equality should be our ideal' (approval of equality; reversecoded). Items were coded such that higher scores indicated higher support of group-based social dominance and an SDO score was created $(\alpha=.80)$. Overall, as expected for members of an HA organization, participants were low on SDO $(M=2.12, S D=0.66)$, indicating an overall inclination for egalitarianism in the sample.

Union Identification motives were assessed with nine items drawn from the union loyalty subscale developed by Gordon, Philpot, Burt, Thomson and Spiller (1980). It included items such as 'I feel a sense of pride being part of this union' or 'My values and the union's values are not very similar' (reverse-coded). A union identification score was created $(\alpha=.87)$.

Union instrumentality motives were assessed with 13 items adapted from the work of Moorman (1991) to reflect the actual union policies. The items of the union instrumentality score $(\alpha=.91)$ tapped participants' perception of job security and safety and fringe benefits such as 'The union Memorandum of Understanding guarantees that you are fairly rewarded regarding your responsibilities' and 'The union guarantees your job security' (outcome-based benefits) as well as union procedures ensuring that decisions were ethical, representative and unbiased, such as 'Having a union ensures that the concerns of all those affected by a decision are heard by supervisors' or 'Overall, having a union ensures that management decisions are made in a fair manner' (process-based benefits). Initially, an outcome-based and a process-based union instrumentality score were created. Preliminary analyses nevertheless revealed that the correlation patterns for the two scores were the same, and when included simultaneously or separately in the models, they yielded identical results for the predicted effects. Therefore, for the sake of parsimony and due to the high correlation of the scores $(r=.60, p<.001)$, the two instrumentality perceptions were combined.

\section{RESULTS}

First, bivariate relations among the variables were observed. Second, the relationship between SDO and active union participation as well as the predicted mechanisms underlying this relationship were investigated. Table 1 shows the expected negative relationships between SDO and reported union participation as well as between SDO and other union-related measures. Union identification was positively related to both perceived union instrumentality and union participation. However, perceived union instrumentality was unrelated to union participation.

To assess the mediating role of union identification in the relationship between SDO and reported union participation, we performed a series of multiple regressions controlling for socio-demographic background variables and union tenure (see Baron \& Kenny, 1986). SDO was negatively related to both union participation $(B=-.39, p<.01)$ and union identification $(B=-.54, p<.001)$. Demonstrating a novel domain of application of 
SDO, we found that the more one accepted group-based domination in society the less one participated in union activities (confirming Hypothesis 1) and the less one felt identified with the union. In line with Hypothesis 2, union identification fully mediated the effect of SDO on union participation. When union participation was simultaneously regressed on SDO and union identification, SDO was no longer a reliable predictor $(B=.08, n s)$, whereas union identification was positively related to participation $(B=.56, p<.001)$. The Sobel test also revealed a reduction in the predicted strength of the SDO after controlling for union identification, $z=-3.50, p<.001$. The exclusion of control variables yielded identical results.

The mediational role of union instrumentality perceptions (Hypothesis 3a) was not investigated because the relationship between perceived union instrumentality (mediator) and union participation (criterion) did not reach significance $(B=.22, S E=0.13$, ns; see also Table 1), and therefore the criteria set for conducting a mediational analysis were not met (Baron \& Kenny, 1986).

Next, we tested the alternative hypothesis regarding the moderating role of perceived union instrumentality. We examined whether the mediating effect of union identification for the SDO-union participation relationship is moderated by perceived union instrumentality such that the relationship between union identification and union participation is particularly strong when unions are perceived as enhancing workplace justice (Hypothesis $3 b)$. That is, we investigated whether, at the second stage of the indirect effect, union instrumentality moderates the path from union identification to union participation (see Figure 1). A moderated mediation occurs when mediation relations are contingent on the level of the moderator. In analyzing the moderated mediation, we followed the procedures recommended by Muller, Judd and Yzerbyt (2005; Preacher, Rucker, \& Hayes, 2007). The independent variables included in the regressions were mean centred. Table 2 shows the results of three regression analyses testing for the moderated mediation controlling for socio-demographic background variables and union tenure.

In line with the initial mediational analysis, the first equation indicated an overall effect of SDO $(B=-.35, p<.05)$ on union participation. However, neither perceived union instrumentality nor SDO $\times$ union instrumentality interaction predicted union participation. The second equation confirmed that SDO $(B=-.39, p<.001)$ as well as perceived union instrumentality $(B=.51, p<.001)$ were related to union identification (the absence of interaction between SDO and union instrumentality excludes that a moderated mediation occurred in the first stage of the indirect effect). In the third equation, a moderated mediation was revealed. When controlling for union identification, SDO $(B=.07, n s)$ was no longer a reliable predictor, whereas union identification $(B=.92, p<.001)$ was still positively related to union participation. Importantly, confirming Hypothesis $3 \mathrm{~b}$, the predicted interaction between perceived union instrumentality and union identification $(B=.64, p<.001)$ was found. The effect of union identification on union participation depended thus on union instrumentality.

To interpret the significant interaction effect of the moderated mediation analysis, conditional indirect effects were examined as suggested by Preacher et al. (2007; SPSS macro retrieved at www.quantpsy.org; see also Edwards \& Lambert, 2007). That is, the product of the two path estimates of the mediation was conditioned to values of the moderator. With focus on the second stage of the indirect effects, we studied the indirect effects between SDO and union participation through union identification at high, intermediate and low levels of perceived union instrumentality (1 SD below mean, mean and $1 S D$ above mean). To obtain accurate standard errors and confidence intervals, we 
Table 2. Moderated mediation model for relationship between SDO and union participation

\begin{tabular}{|c|c|c|c|c|c|c|}
\hline & \multicolumn{2}{|c|}{$\begin{array}{c}\text { Equation } 1 \\
\text { (criterion union } \\
\text { participation) }\end{array}$} & \multicolumn{2}{|c|}{$\begin{array}{c}\text { Equation 2 } \\
\text { (criterion union } \\
\text { identification) }\end{array}$} & \multicolumn{2}{|c|}{$\begin{array}{c}\text { Equation } 3 \\
\text { (criterion union } \\
\text { participation) }\end{array}$} \\
\hline & $B$ & $S E$ & $B$ & $S E$ & $B$ & $S E$ \\
\hline \multicolumn{7}{|l|}{ Predictors } \\
\hline SDO & $-.35^{*}$ & .14 & $-.39 * * *$ & .09 & .07 & .14 \\
\hline Union instrumentality & .12 & .14 & $.51 * * *$ & .08 & -.23 & .13 \\
\hline SDO $\times$ Union instrumentality & .06 & .19 & .07 & .12 & .30 & .18 \\
\hline Union identification & & & & & $.92 * * *$ & .15 \\
\hline Union identification $\times$ Union $\mathrm{i}$ & & & & & $.64 * * *$ & .16 \\
\hline \multicolumn{7}{|c|}{ Background variables } \\
\hline Gender (men) & .37 & .19 & -.16 & .12 & $.54 * *$ & .17 \\
\hline Age & .01 & .01 & $.02 *$ & .01 & -.01 & .01 \\
\hline \multicolumn{7}{|l|}{ Ethnicity (white) } \\
\hline Latino & -.49 & .30 & -.06 & .19 & -.45 & .26 \\
\hline Asian American & -.41 & .38 & -.17 & .24 & -.34 & .33 \\
\hline African American & -.30 & .30 & -.21 & .19 & -.04 & .26 \\
\hline Other & .23 & .41 & .05 & .25 & .18 & .35 \\
\hline Union tenure & $.03 * *$ & .01 & .00 & .01 & $.02 *$ & .01 \\
\hline Adjusted $R^{2}$ & .25 & & .40 & & .45 & \\
\hline
\end{tabular}

Outcome variables on a 5-point scale ( 1 =never/strongly disagree, $5=$ always/strongly agree $)$.

$* p<.05 ; * * p<.01 ; * * * p<.001$;

computed indirect effects from unstandardized regression weights with 3000 bootstrap resamples. The indirect effect of SDO on union participation through union identification (mediation) was strongest at high levels of perceived union instrumentality (indirect effect = $-0.630, S E=0.153,95 \% \mathrm{CI}=-.945$ to -.348 ), followed by intermediate (indirect effect $=$ $-0.432, S E=0.095,95 \% \mathrm{CI}=-.622$ to -.245$)$ and low levels of perceived union instrumentality (indirect effect $=-0.233, S E=0.066,95 \% \mathrm{CI}=-.369$ to -.114 ). The mediational effect of union identification for the association between SDO and union participation was the strongest for members perceiving that unions affect workplace justice. Thus, although union instrumentality did not have a direct effect on union participation, it reinforced the effect of union identification on union participation.

Finally, of the background variables included in the models, union tenure and gender influenced union participation. The longer one had been member of the union, the more one participated in its activities. Men participated more than women in union activities. The older members, in turn, identified more with the union. The results of the tested models remained identical when these variables were omitted.

\section{DISCUSSION}

The aim of this study was to apply social dominance theory in a novel domain: union participation. The study thus bridged social dominance theory and labour studies literature to further understand the psychological antecedents of union activism. Labour unions exemplify HA organizations as their general aim is to reduce power distances between 
employees and employers in organizations. According to social dominance theory, then, people opposing group-based dominance systems are more likely to participate in union activities and identify more strongly with HA institutions than those supporting groupbased dominance systems. Supporting this line of reasoning, we demonstrated with a sample of union members that SDO was negatively related to self-reported union participation behaviour (confirming Hypothesis 1) and that union identification fully mediated this relationship (confirming Hypothesis 2). Hypotheses 3a and 3b were derived to investigate the mediating or moderating role of perceived union instrumentality in the relationship between SDO and union participation. Although the somewhat surprising absence of a direct relationship between perceived union instrumentality (mediator) and union participation (criterion) excluded a mediational relationship (rejecting Hypothesis 3a), the results of the current study demonstrated the moderating role of perceived union instrumentality. Unlike research demonstrating additive effects of identity and instrumental motivations to explain collective action (e.g. Stürmer \& Simon, 2004), we found an interactive effect between identity and instrumental motivations. Confirming Hypothesis $3 b$, we revealed a stronger relationship between union identification and participation when the union was perceived as supporting job security, protecting wages or having an efficient grievance system. The mediational effect of union identification was lowest for those who doubted that the union plays an instrumental role for working conditions. Thus, although instrumental motivations alone did not predict union participation, these motivations enhance the effect of commitment to the union on union participation. This finding is in line with social dominance theory. Group-based injustice is rejected and considered illegitimate by low SDO_-and consequently more identifying-members. Because unions represent HA institutions, the coherence between the unions' aims and one's social beliefs drives low SDO individuals to participate in counterdominant union activities. The integration of social dominance theory with research on unions in the current study also responds to criticisms that the theory has been overly focussed on ethnic group relations while neglecting other pervasive forms of inequality such as inequality between those who own and control the means of production and those who do the production (Lehmiller \& Schmitt, 2007).

\section{PRACTICAL IMPLICATIONS}

In light of the observation at the outset of this article that union membership has declined, the practical implications of this study need some thought. Namely, how to increase union participation behaviour? In general, the results showed the dominance of identity motivations over instrumental motivations in explaining the link between SDO and union participation. Although this finding highlights the importance of group identification in enhancing collective action (Kelly, 1997; Stürmer \& Simon, 2004), union leaders' and activists' efforts to increase and foster pride and loyalty towards the union or intrinsic involvement based on internalization of union standards will not suffice to get workers to participate in union activities. To enhance participation, unions must also highlight their instrumental-extrinsic-benefits for workplace justice. Nevertheless, Pratto, Tatar and Conway-Lanz (1999) found high SDO individuals to favour merit-based distributive justice and low SDO respondents giving more value to need-based distributive justice. Indeed, as unions traditionally favour need- or tenure-based instead of merit-based benefits, the egalitarian aspects of union instrumentality will appeal less to people accepting and 
endorsing social inequalities. Through participation in union activities, members are further socialized in HA ideological values (e.g. Guimond et al., 2003). People high on SDO are less likely to join unions in the first place.

Although the study of union participation by definition examines union members' behaviour, the motivations of potential members should also be considered. In the current study, union instrumentality did not directly influence union participation, but prior research has suggested that instrumental concerns predict joining unions (e.g. Blader, 2007) and precede union commitment in decisions to join (Fullagar \& Barling, 1989). Similarly, individuals may decide not to join because they oppose union ideologies or because they consider the unions inefficient in improving working conditions. To understand who joins a union requires going beyond ideological orientations and union-related motivations. For example, employees' evaluations of their organization's procedural justice (i.e. fairness of decision making and equality of treatment) also determine decisions to join (e.g. Blader, 2007). Finally, different unions will attract different people. A union representing a narrow sector of jobs focussing on workers' needs in this context may attract members with only instrumental concerns. A union calling for broader solidarity that represents working class in general and relates with other social movements will, in turn, have a different membership base.

\section{LIMITS AND CONCLUSIONS}

The present study has a few caveats. First, the generalization of the results is limited because the study was carried out among public service employees from one union. Unions in the private and the public sector have different positions in terms of density and power, which might itself influence participation in union activities (Lipset \& Katchanovski, 2001). Because unionization has decreased in particular in the private sector, future research should test the model outlined in this research in both public and private sector unions in the USA and in other countries.

Second, as participation in the survey was voluntary, presumably members' willingness to answer reflected positive union attitudes and behaviour. Common method bias is also a potential shortcoming as attitudes and self-reported behaviour concern the same target: the union. In the current research, objective behavioural measures could, however, not be obtained.

Third, existing union members are potentially lower in SDO than nonmembers as members typically join a union for countering power differences between employees and employers. In keeping with social dominance theory assumptions, low SDO levels can be expected in research on counterdominance behaviour-and especially in HA institutions - as the very objective of such behaviour and such organizations is to challenge or defy the existing societal hierarchy. Although range restriction in the SDO measure was not revealed in the current study, if anything this would have resulted in underestimated correlations between measures. To assess the boundaries of the model outlined in this article, further research should nevertheless compare SDO levels and their effect between union members and nonmembers.

Fourth, to the extent that the sample was cross-sectional, the possibility of reverse causality between the variables in the theoretical model cannot be excluded. This study leaves open the possibility that union participation shapes identification, instrumentality 
and SDO. Indeed, a reciprocal relationship between SDO and union identification is compatible with social dominance theory (Sidanius \& Pratto, 1999). Only longitudinal or experimental studies would permit confirmation of the proposed causal relationship and contribution to the debate opposing the causal effect of attitudes on behaviours to the reinforcing effect of behaviours on attitudes. Nevertheless, the revealed pattern of attitudes predicting union behaviour is consistent with the theoretical traditions examining union behaviour and, for example, followed the conclusions of a longitudinal study of Fullagar et al. (2004), who established a causal relationship between union commitment and participation. Moreover, ample evidence exists of the relationship between SDO and legitimizing myths (Sidanius \& Pratto, 1999; Sidanius et al., 1996).

Finally, the distinction between HE and HA institutions is not definite. For example, the police have high unionization rates, although the police forces are considered a HE institution as their functioning contribute to the maintenance of group-based hierarchies between dominant and subordinate ethnic minority groups. As individuals are members of multiple groups and hold multiple identities (e.g. police and union member), when investigating union behaviour-and participation in collective action in general-it is important to account for the appropriate level of identification (Blader, 2007). In the current study, we assumed that unions are HA institutions, but future studies should investigate how both high and low SDO people perceive unions.

Notwithstanding these limitations, this research is a first step in applying social dominance theory to a union context, and in industrial relations research more generally. Despite the similar ideological underpinnings (e.g. liberalism, left-wing political orientation) of opposition to group-based hierarchies and of support to the labour movement, to our knowledge, no research has previously established a link between these notions. This line of research can improve our understanding of antecedents of union joining and participation and, ultimately, reveal ways to encourage those holding egalitarian values to claim the upholding of these values at the workplace.

\section{ACKNOWLEDGEMENTS}

The authors are grateful to Franciska Krings and Christian Staerklé for insightful comments on a previous draft. They also thank SEIU Local 721 Southern California Public Service Workers and Benjamin Uminsky for their cooperation with this project. Fanja Auer's Master thesis was part of the research presented in this article.

\section{REFERENCES}

Aryee, S., \& Chay, Y. W. (2001). Workplace justice, citizenship behaviour, and turnover intentions in a union context: Examining the mediating role of perceived union support and union instrumentality. Journal of Applied Psychology, 86, 154-160.

Bamberger, P. A, Kluger, A. N., \& Suchard, R. (1999). The antecedents and consequences of union commitment: A meta-analysis. The Academy of Management Journal, 42, 304-318.

Baron, R. M., \& Kenny, D. A. (1986). The moderator-mediator variable distinction in social psychological research: Conceptual, strategic and statistical considerations. Journal of Personality and Social Psychology, 51, 1173-1182.

Blader, S. L. (2007). What leads organizational members to collectivize? Injustice and identification as precursors of union certification. Organization Science, 18, 108-126. 
Chaison, G. (2006). The changing role of unions: A review essay. Journal of Labor Research, 27, 423-434.

Cohen-Charash, Y., \& Spector, P. E. (2001). The role of justice in organizations: A meta-analysis. Organizational Behavior and Human Decision Processes, 86, 278-321.

Cornfield, D. B. (1991). The US labor movement: Its development and impact on social inequality and politics. Annual Review of Sociology, 17, 27-49.

Edwards, J. R., \& Lambert, L. S. (2007). Methods for integrating moderation and mediation: A general analytical framework using moderated path analysis. Psychological Methods, 12, 1-22.

Fullagar, C., \& Barling, J. (1989). A longitudinal test of the antecedents and consequences of union loyalty. Journal of Applied Psychology, 74, 213-227.

Fullagar, C. J., Clark, P. F., Gallagher, D. G., \& Carroll, A. E. (2004). Union commitment and participation: A 10 year longitudinal study. Journal of Applied Psychology, 89, 730-737.

Gordon, M. E., Philpot, J. W., Burt, R. E., Thompson, C. A., \& Spiller, W. E. (1980). Commitment to the union: Development of a measure and an examination of its correlates. Journal of Applied Psychology, 65, 479-499.

Guimond, S., Dambrun, M., Michinov, N., \& Duarte, S. (2003). Does social dominance generate prejudice? Integrating individual and contextual determinants of intergroup cognitions. Journal of Personality and Social Psychology, 84, 697-721.

Haley, H., \& Sidanius, J. (2005). Person-organization congruence and the maintenance of groupbased social hierarchy: A social dominance perspective. Group Processes and Intergroup Relations, 8, 187-203.

Haslam, S. A. (2001). Psychology in organizations. The social identity approach. London: Sage.

Henry, P. J., Sidanius, J., Levin, S., \& Pratto, F. (2005). Social dominance orientation, authoritarianism, and support for intergroup violence between the Middle East and America. Political Psychology, 26, 569-584.

Johnson, B. N., \& Jarley, P. (2004). Justice and union participation: An extension and test of mobilization theory. British Journal of Industrial Relations, 42, 543-562.

Kelloway E. K., \& Barling, J. (1993). Member's participation in local union activities: Measurement, prediction and replication. Journal of Applied Psychology, 78, 262-279.

Kelly, J. (1997). The future of trade unionism: injustice, identity and attribution. Employee Relations, $19,400-414$.

Kelly, C., \& Breinlinger, S. (1996). The social psychology of collective action. Identity, injustice, and gender. London: Taylor \& Francis.

Kelly, C., \& Kelly, J. (1992). Who gets involved in collective action? Social psychological determinants of individual participation in trade unions. Human Relations, 47, 63-88.

Klandermans, B. (1997). The social psychology of protest. Oxford: Blackwell.

Lehmiller, J. J., \& Schmitt, M. T. (2007). Group domination and inequality in context: Evidence for the unstable meanings of social dominance and authoritarianism. European Journal of Social Psychology, 37, 704-724.

Levin, S., Henry, P. J., Pratto, F., \& Sidanius, J. (2003). Social dominance and social identity in Lebanon: Implications for support of violence against the West. Group Processes \& Intergroup Relations, 6, 353-368.

Lipset, S. M. \& Katchanovski, I. (2001). The future of private sector unions in the U.S. Journal of Labor Research, 22, 229-244.

McFarlane Shore, L., Tetrick, L. E., Sinclair, R. R., \& Newton, L. A. (1994). Validation of a measure of perceived union support. Journal of Applied Psychology, 79, 971-977.

Moorman, R. H. (1991) Relationship between organizational justice and organizational citizenship behaviors: Do fairness perceptions influence employee citizenship? Journal of Applied Psychology, 76, 845-855.

Morrow, P. C., \& McElroy, J. C. (2006). Union loyalty antecedents: A justice perspective. Journal of Labor Research, 27, 75-87.

Muller, D., Judd, C. M., \& Yzerbyt, V. Y. (2005). When moderation is mediated and mediation is moderated. Journal of Personality and Social Psychology, 89, 852-863.

Newton, L. A., \& Shore, L. M. (1992). A model of union membership: instrumentality, commitment and opposition. Academy of Management Review, 17, 275-298.

Panagopoulos, C., \& Francia, P. L. (2008). Labor unions in the United States. Public Opinion Quarterly, 72, 134-159. 
Pratto, F., Sidanius, J., \& Levin, S. (2006). Social dominance theory and the dynamics of intergroup relations: Taking stock and looking forward. European Review of Social Psychology, 17, 271-320.

Pratto, F., Sidanius, J., Stallworth, L. M., \& Malle, B. F. (1994). Social dominance orientation: A personality variable predicting social and political attitudes. Journal of Personality and Social Psychology, 67, 741-763.

Pratto, F., Tatar, D. J., \& Conway Lanz, S. (1999). Who gets what and why: Determinants of social allocations. Political Psychology, 20, 127-150.

Preacher, K. J., Rucker, D. D., \& Hayes, A. F. (2007). Addressing moderated mediation hypotheses: Theory, methods, and prescriptions. Multivariate Behavioral Research, 42, 185-227.

Prowse, P. J., \& Prowse, J. M. (2006). Are nonunion workers different to their union colleagues? Evidence from public services. Industrial Relations Journal, 37(3), 222-241.

Sidanius, J., \& Pratto, F. (1999). Social dominance: An intergroup theory of social hierarchy and oppression. New York: Cambridge University Press.

Sidanius, J., Levin, S., \& Pratto, F. (1996). Consensual social dominance orientation and its correlates within the hierarchical structure of American society. International Journal of Intercultural Relations, 20, 385-408.

Snape, E. \& Redman, T. (2004). Exchange or covenant? The nature of the member-union relationship. Industrial Relations, 43, 855-873.

Stürmer, S., \& Simon, B. (2004). Collective action: Towards a dual-pathway model. European Review of Social Psychology, 15, 59-99.

Sverke, M., \& Kuruvilla, S. (1995). A new conceptualization of union commitment: Development and test of an integrated theory. Journal of Organizational Behavior, 16, 505-532.

Tan, H. H., \& Aryee, S. (2002). Antecedents and outcomes of union loyalty: A constructive replication and an extension. Journal of Applied Psychology, 87, 715-722.

Tetrick, L. E., Mc Clurg, L. N., Shore, L. M., \& Vandenberg, R. J. (2007). A model of union participation: The impact of perceived union support, union instrumentality, and union loyalty. Journal of Applied Psychology, 92, 820-828.

Youngblood, S. A., DeNisi, A. S., Molleston, J. L. \& Mobley, W. H. (1984). The impact of work environment, instrumentality beliefs, perceived labor union image, and subjective norms on union voting intentions. The Academy of Management Journal, 27, 576-590. 